\title{
Diagnostic Efficiency of a New Candida albicans Rapid Test Device and the Importance of some Risk Factors of Vulvovaginal Candidiasis in Mosul City
}

\author{
Heba M. Alghnam Nawfal Y. AL-Dabbagh \\ Department of Microbiology \\ College of Medicine \\ University of Mosul
}

(Received 26/12/2011;Accepted 14/2/2012)

\begin{abstract}
The objective of this study is to evaluate the importance of Candida albicans rapid test device and to evaluate the importance of some risk factors in the diagnosis of Candida albicans in vaginal discharge and to compare this test with other diagnostic methods. One hundred sixty women were investigated in this study. Results showed no statistical relationship between the age and the occupation of the patient and the incidence of fungal vaginitis. Relationship between recent use of antibiotics and infection was statistically evident. The sensitivity of the rapid test device for the diagnosis of VVC was $87.9 \%$ versus direct microscopical examination which has $64.5 \%$ sensitivity. We conclude that the rapid test device provided a rapid and better results than conventional microscopy and culture for the diagnosis of VVC. This easy-to-perform diagnostic test will be useful to practitioners treating women with symptoms of fungal vaginitis.
\end{abstract}

Keywords : Candida albicans, diagnosis, vaginal discharge, Rapid test device.

\section{الهماءة التشخيصية الفهص السرع لامبيضلت البيضاء ولهمية بهض عوللك الظلورة لاء المبيضلت الفرهي المهبلي في مدينة الموطل}

\section{الملغص}

الهذف من هله الدربلسة هو لغرض نقيم اهمية الفحص المربع للمبيضلت البيضاء و ققيم أهمية بعض المبض

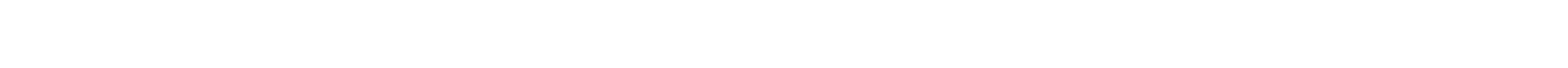

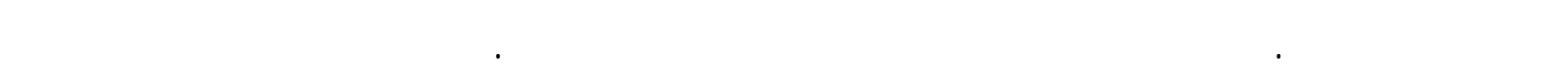

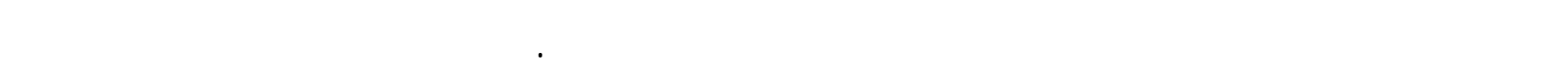

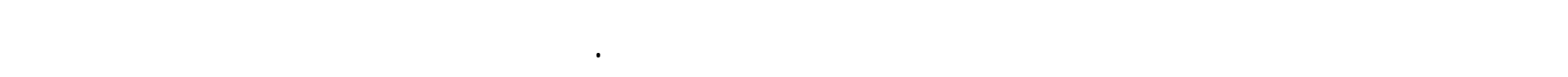
اللسريع لغرض تشخيص داء المبيضلت الفرجي المهبلي هي 87.9 \% بينما كافت هشلسية الفحص المبلث -ر 


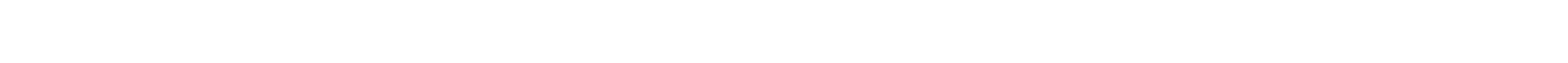

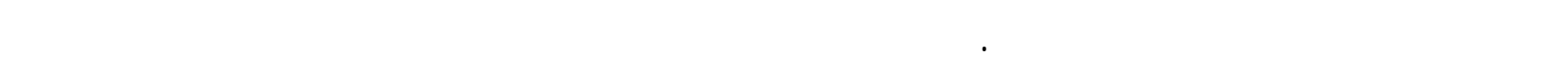
باءراض التهب المهل الفطري.

الكاملت الدالة: المبيضلت البيضاء، تشخيص، الإفراز المهبلي، فحص للسربع.

\section{INTRODUCTION}

Candida albicans is a diploid fungus and a causal agent of opportunistic oral and genital infections in humans, (Denfert and Hube, 2007). Vulvovaginal candidiasis is the second most common cause of vaginal symptoms after bacterial vaginosis (Nester et al., 2007). Candida albicans accounts for approximately $80-90 \%$ of all vulvovaginitis cases. (Adeb et al., 2011). predisposing factor include, pregnancy, use of high-oestrogen oral contraceptives, Diabetes Mellitus, taking of wide spectrum antibiotics and corticosteroid, premenstrual phase of the menstrual cycle, depressed cell mediated immunity (e.g. AIDS) and obesity. (Nviriesy, 2008) Infection of the vagina or vulva may cause severe itching, burning, soreness, irritation, and a whitish or whitish-gray cottage cheese-like discharge, often with a curd-like appearance. (Warren, 2010).

The necessary investigations to be performed in Candida vulvo-vaginitis include; $\mathrm{pH}$ remains normal (4-4.5) (Thulkar et al., 2010). The vaginal discharge is subjected to both unstained and stained preparation. Unstained preparation include a saline wet mount to rule out Trichomonas or a $\mathrm{KOH}$ wet mount. Absence of pus cells or their presence in small numbers is notable in Candida infections. Stained preparations include Gram stain and Papanicolaou stain to rule out Trichomonas. Confirmation of the fungal etiological agent is achieved by culture on Sabouraud's dextrose agar. (Yehia, 2009).

The clinical symptoms of vulvovaginal candidiasis (VVC) are nonspecific, and misdiagnosis is common, leading to a delay in the initiation of antifungal treatment. (Marotleblond et al., 2009). So several rapid diagnostic tests have been developed over the past 25 years in an attempt to speed up the diagnosis of VVC. (Reed et al., 1992).Latex particle agglutination (LPA) was found to be more sensitive than $\mathrm{KOH}$ microscopy and was more specific than other diagnostic criteria (Evans et al., 1986). In the present study the Rapid test device was used for the rapid diagnosis of $\mathrm{VVC}$ and to evaluate this test in comparison to other test including compaired microscopy and culture. As far as we know from the literature cited ,this is the first time in Iraq that the Rapid test device is used for the diagnosis of Candida in vaginal discharge. The StrongStep ${ }^{\circledR}$ Candida albicans Rapid Test uses color immunochromatographic, capillary flow technology. The test procedure requires the solubilization of the Candida proteins from a vaginal swab by mixing the swab in Sample Buffer. If Candida is present in the sample there will be a visible test line along with the control line will indicate a positive result.

\section{MATERIAL AND METHODS}

The study was carried out during the period from January 2011, to July 2011 at AlBatool and Al-khansaa Teaching Hospitals in Mosul City. Full informational data were recorded from 160 female attending out Patient Clinics of these hospitals complaining from 
vaginal discharge. The collected data included name, age, residency, occupation and vaginal discharge including it's amount, color, consistency, odor and duration. Data was also analyzed in term of the use of antibiotics. Three vaginal swabs were taken from each patient. The first swab was placed in tube containing $2 \mathrm{ml}$ of normal saline for wet mount examination, It was examined under X10 and X40 magnification of light microscope. Candida albicans were identified by its typical hyphe and budding spores (dimorphic fungi). The second swab were cultured on. Sabouraud's Dextrose Agar which incubated at $37^{\circ} \mathrm{C}$ for 24-48 hours ( Yehia, 2009).

In order to identify the albicans species; Germ tube test was done by Using a sterile loop and a small portion of a pure colony of $C$. albicans was inoculated in to sterile test tubes containing $0.5 \mathrm{ml}$ human sera. The resulting mixture was incubated aerobically at $37 \mathrm{oC}$ for 2-3 hours then, a drop of the yeast-serum mixture was placed on a clean slide and examined microscopically. The appearance of small filaments projecting from the cell surface confirmed formation of germ tubes. ( Isibor et al., 2005).

The third swab was used for subsequent evalution of Candida albicans rapid test kit. This is test is used for qualitative detection of Candida albicans within 10-20 minutes .Its an important advance in improving the diagnosis of VVC. It is produced by (Liming BioProducts Co., Ltd.,) in China.

The test procedure requires the solubilization of the Candida proteins from a vaginal swab by mixing the swab in Sample Buffer. (Fig. 1) Then the mixed sample buffer is added to the test cassette sample well and the mixture migrates along the membrane surface. If Candida is present in the sample, it will form a complex with the primary anti- Candida antibody conjugated to colored particles. The complex will then be bound by a second antiCandida antibody coated on the nitrocellulose membrane. A negative result show only the control line. (Fig. 2) While the appearance of a visible test line along with the control line will indicate a positive result. (Fig. 3). The result was statically analyzed using the following stastical methods: chi -square $\left(x^{\wedge} 2\right)$ test was used to find stastical difference between the study group using (Minitab Program). P value less than 0.05 considered to be significant. The validity indicators used for comparisons between different methods used for the examination of C. albicans were sensitivity, specificity, positive predictive value (PPV) and negative predictive value (NPP) as stated by Gordis (1996).

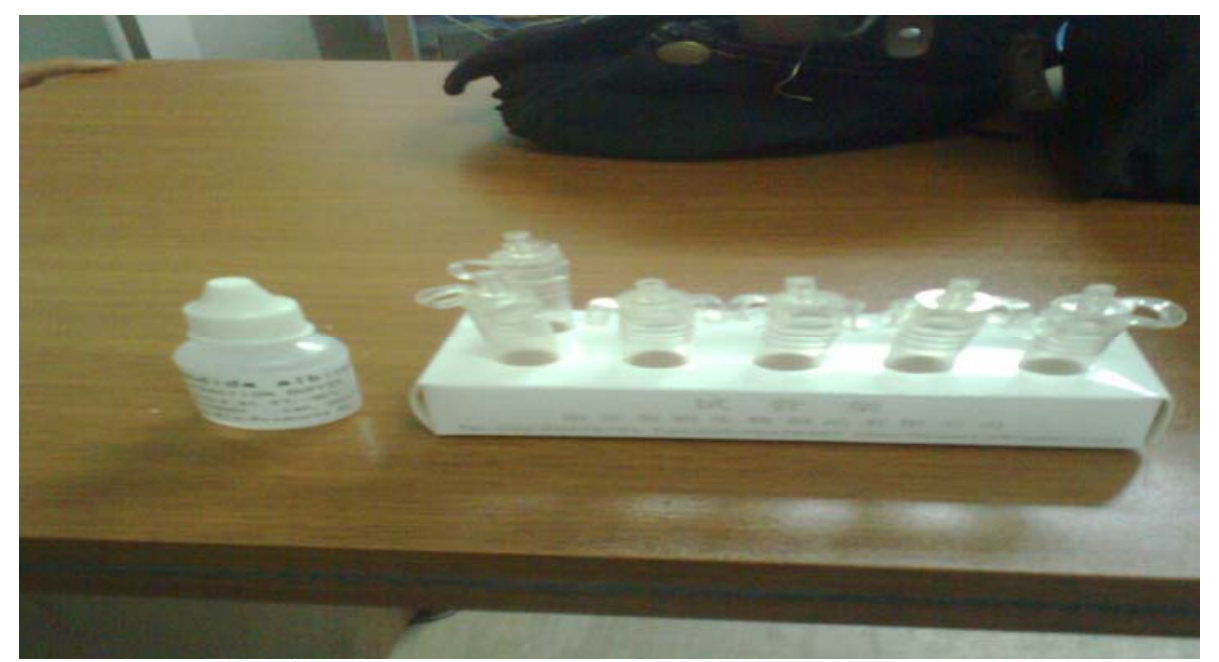

Fig. 1: Extraction tubes contain buffer solution to be mixed with the vaginal swab. $(10.19 * 12.7 \mathrm{~cm})$ 


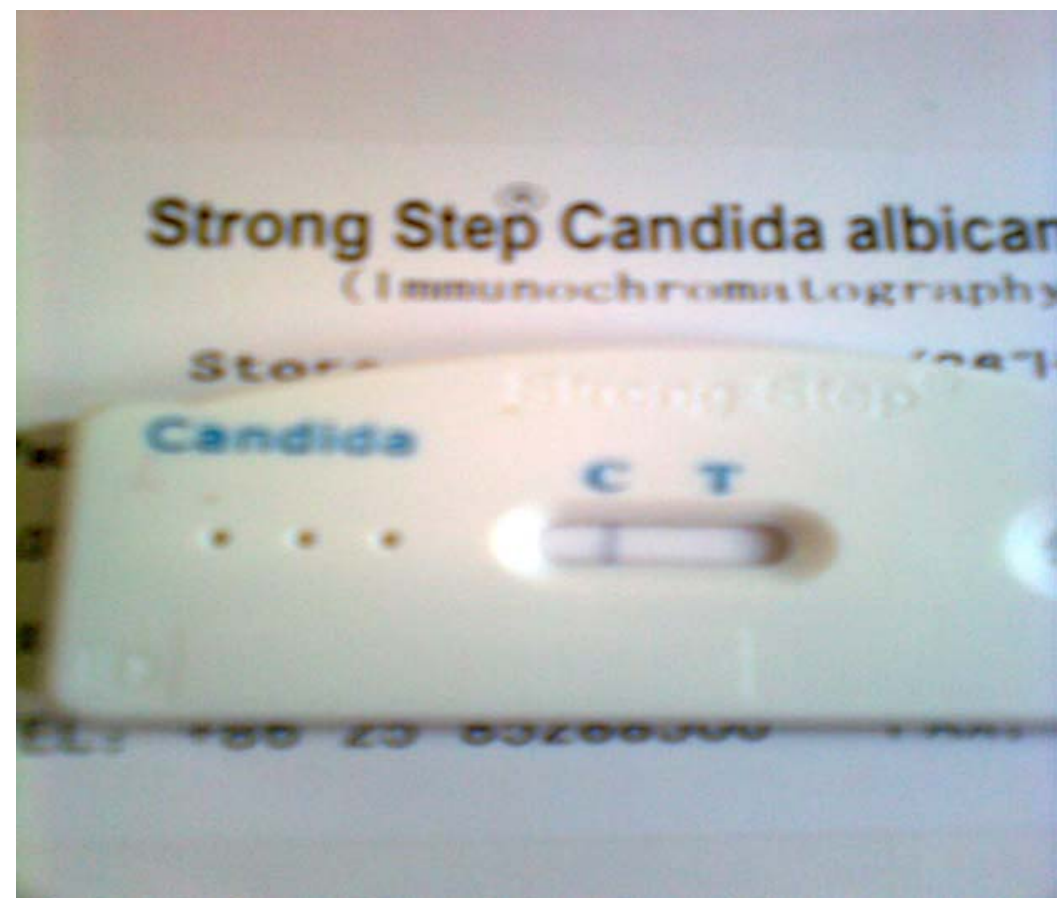

Fig. 2: A negative Candida albicans rapid test device (one blue line in control region). $(10.19 * 14.72 \mathrm{~cm})$

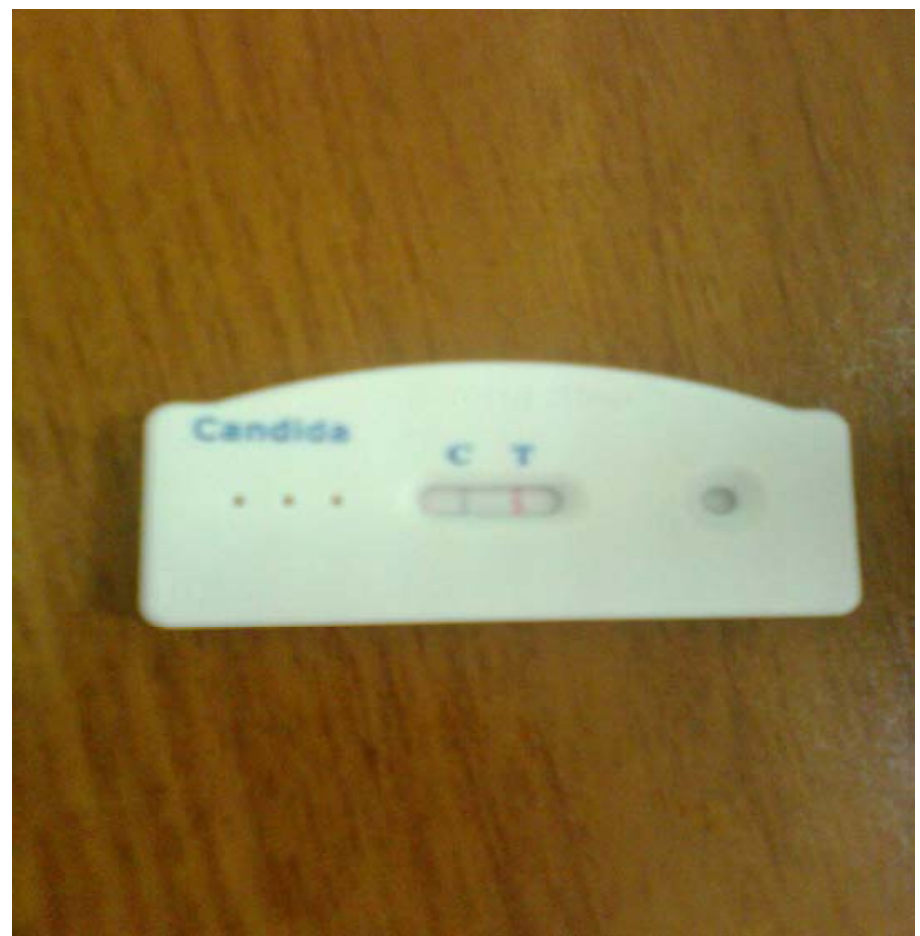

Fig. 3: A positive Candida albicans rapid test device (one blue line in control region and a red line in the test region $).(10.19 * 12.77 \mathrm{~cm})$. 


\section{RESULTS AND DISCUSSION}

\section{The frequency of Candida albicans infection according to the age}

The highest frequency of Candida albicans infection was most commonly seen among the 21-30 years age group (38.7\%) and followed by $31-40$ years age group $(32.3 \%)$ while the lowest incidence of infection was found among $\leq 20$ years age group $(6.5 \%)$. There was no statistical difference between the positive and negative cases at different age groups as shown in (Table 1). This is in agreement with the results obtained by Begum (2004) who observed peak age of having C. albicans among the 25-29 years age group comprising (37.8\%) of cases. Other investigators reported similar results, Al-Quaiz (2000) conducted a study with 2719 females attending university Primary Care Clinic in Riyadh, who underwent screening for vaginal discharge; and reported that the peak age group for vaginal infection was 25-30 years. Another study in Syria showed that vaginal candidiasis was more common among women aged between 30-45. (Al-Karim et al., 2007). It seems that during this reproductive period with highest sexual activity the chance of having C. albicans infection is increased.

Table 1: The frequency of Candida albicans infection according to the age $(n=160)$.

\begin{tabular}{|c|c|c|c|c|c|c|}
\hline \multirow{2}{*}{$\begin{array}{c}\text { Age } \\
\text { (years) }\end{array}$} & \multicolumn{2}{|c|}{$\begin{array}{l}\text { Candida albicans } \\
\text { Positive cases }\end{array}$} & \multicolumn{2}{|c|}{$\begin{array}{l}\text { Candida albicans } \\
\text { Negative cases }\end{array}$} & \multicolumn{2}{|c|}{ Total } \\
\hline & No. & $\%$ & No. & $\%$ & No. & $\%$ \\
\hline$\leq 20$ & 2 & 6.5 & 16 & 12.4 & 18 & 11.3 \\
\hline $21-30$ & 12 & 38.7 & 46 & 35.7 & 58 & 36.3 \\
\hline $31-40$ & 10 & 32.3 & 27 & 20.9 & 37 & 23.1 \\
\hline$\geq 41$ & 7 & 22.5 & 40 & 31 & 47 & 29.4 \\
\hline Total & \multicolumn{2}{|c|}{31} & \multicolumn{2}{|c|}{129} & \multicolumn{2}{|c|}{160} \\
\hline
\end{tabular}

\section{The relation between Candida albicans and the occupation:}

It was found that from 31 positive cases of Candida albicans, 21(67.7\%) were housewives and 10(32.3\%) were employees. There was no statistical difference between the positive and negative cases among housewives and employees as shown in (Table 2 ). This is in accordance with the results obtained by Al-Quaiz (2000) who found that 19 (11\%) of these patients were employed and 156(89\%) were unemployed (housewives). This result may be due to the better hygienic habits of the employees and since they are prone to ask for medical advice than those housewives who may deal with vaginal discharge and minor irritation as being trivial or normal. 
Table 2: The relation between Candida albicans and the occupation $(n=160)$.

\begin{tabular}{|c|c|c|c|c|c|c|}
\hline \multirow[t]{2}{*}{ Occupation } & \multicolumn{2}{|c|}{$\begin{array}{l}\text { Candida albicans } \\
\text { Positive cases }\end{array}$} & \multicolumn{2}{|c|}{$\begin{array}{l}\text { Candida albicans } \\
\text { Negative cases }\end{array}$} & \multicolumn{2}{|c|}{ Total } \\
\hline & No . & $\%$ & No. & $\%$ & No. & $\%$ \\
\hline House wife & 21 & 67.7 & 104 & 80.6 & 125 & (78.1) \\
\hline Employee & 10 & 32.3 & 25 & 19.4 & 35 & $(21.9)$ \\
\hline Total & \multicolumn{2}{|c|}{31} & \multicolumn{2}{|c|}{129} & \multicolumn{2}{|c|}{160} \\
\hline
\end{tabular}

$\chi^{2}=2.426 \quad \mathrm{DF}=1 ; \quad \mathrm{P}-$ Value $=0.119($ not significant $)$

Frequency of Candida albicans according to the antibiotic used:

Among the cases who have a history of recent use of antibiotics 20 (64.5\%) cases were found to have $C$. albicans infection. There was a statistical difference between positive and negative cases according to the antibiotic use as shown in (Table 3). This is more than what have been reported by Begum (2004) who found that among the cases who had a history of recent use of antibiotics, 5(21.7\%) cases only were found to have C. albicans infection. Among the recent antibiotics non-users, C. albicans was present in $11(35.49 \%)$ which is more than that reported by Begum (2004) who stated that among this group C. albicans was found in 40(14.4\%). The present findings is in general agreement with the studies done by Al -Quaiz (2000) who found that the vaginal infection rate among those who used antibiotic were $71.4 \%$. This is because antibiotics affect the balance of bacteria in the vagina allowing organisms as C. albicans to multiply more rapidly. This study is also in accordance with the result obtained by Al- Karim (2007) who found that from 66 cases of positive yeast culture only $21(31.82 \%)$ had a history of antibiotic uses.

Table 3: Frequency of Candida albicans according to the recent use of antibiotic.

\begin{tabular}{|c|c|c|c|c|c|c|}
\hline \multirow{2}{*}{$\begin{array}{c}\text { Recent Use of } \\
\text { antibiotics }\end{array}$} & \multicolumn{2}{|c|}{$\begin{array}{c}\text { Candida } \\
\text { albicans } \\
\text { Positive cases } \\
\end{array}$} & \multicolumn{2}{|c|}{$\begin{array}{c}\text { Candida albicans } \\
\text { Negative cases }\end{array}$} & \multicolumn{2}{|c|}{ Total } \\
\hline & No & $\%$ & No. & (\%) & No. & (\%) \\
\hline Yes & 20 & 64.5 & 28 & 21.7 & 48 & (30) \\
\hline No & 11 & 35.5 & 101 & 78.3 & 112 & (70) \\
\hline Total & \multicolumn{2}{|c|}{31} & \multicolumn{2}{|c|}{129} & \multicolumn{2}{|c|}{160} \\
\hline
\end{tabular}


A comparison between different diagnostic methods for the detection of Candida albicans:

The results showed that $C$. albicans rapid test kit for the detection of $C$. albicans antigen showed an infection rate of 29 from 31(93.5) cases and culture showed infection rate of 31 cases $(100 \%)$ while direct microscopical examination had $22(70.9 \%)$, as presented in (Table 4).

Table 4(a): A comparison between different diagnostic methods for the detection of Candida albicans:

\begin{tabular}{|c|c|c|c|c|c|}
\hline \multirow[t]{2}{*}{ Test } & \multicolumn{2}{|c|}{$\begin{array}{l}\text { Candida albicans } \\
\text { Positive cases** }\end{array}$} & \multicolumn{2}{|c|}{$\begin{array}{l}\text { Candida albicans } \\
\text { Negative cases }\end{array}$} & \multirow[t]{2}{*}{ Total } \\
\hline & No. & $(\%)$ & No. & $(\%)$ & \\
\hline $\begin{array}{c}\text { Direct } \\
\text { microscopical } \\
\text { examination }\end{array}$ & 22 & 70.9 & 138 & 86.3 & 160 \\
\hline Culture* & 31 & 100 & 129 & 80.6 & 160 \\
\hline $\begin{array}{c}\text { C. albicans rapid } \\
\text { test kit }\end{array}$ & 29 & 93.5 & 131 & 81.9 & 160 \\
\hline
\end{tabular}

* The growth of Candida albicans species was confirmed by (Germ tube test) Non albicans species were neglected.

** From total positive cases (i.e. 31)

Table 4 (b): Comparison between Sensitivity and Specificity of wet mount, and the rapid kit for diagnosis of $C$. albicans (the culture is taken as a gold standard).

\begin{tabular}{|c|c|c|c|c|}
\hline Test & Sensitivity \% & Specificity\% & NPV \% & PPV \% \\
\hline Wet mount & 64.5 & 98.4 & 92.02 & 90.9 \\
\hline The rapid test & 87.9 & 98.4 & 96.9 & 93.1 \\
\hline
\end{tabular}

\section{Wet mount}

Visualization of pseudohyphae and budding yeast cells are typical of many Candida species. Wet mount for detection of $C$. albicans in this study can detect $70.9 \%$ of the positive cases. This is in accordance with the study done by Al- Karim et al., (2005) in Syria, who found that direct microscopical examination can diagnose $66.67 \%$ of the cases of VVC and the study from India in which $77 \%$ of the cases diagnosed by this methods, however, a study done by Goswami et al., (2000) reported even more positively by this test $(94.8 \%)$. This is depend on the experience of the examiner. 


\section{Culture}

Vaginal culture for C. albicans is useful if a wet mount is negative for hyphae but the patient has symptoms and discharge or other signs suggestive of vulvovaginal candidiasis on examination (Linda and Eckert, 2006). The disadvantage of cultures are that they require at least 2 days to complete and get the diagnosis which delay initiation of treatment. (Sobel, 1998 ; Ozturk et al., 2006)

In this study by using the culture method, the positive cases of C. albicans was increased from $70.9 \%$ by wet mount to $100 \%$ by culture which is in accordance with other reports such as that done by Al-Karim et al., (2005) in which (21 cases from $21 \mathrm{swab})$ $100 \%$ of the VVC cases can be diagnosed by culture in comparison to (14 cases from 21 swab) $66.67 \%$ by wet mount. Sabouraud dextrose agar, remain the gold standard for diagnosis of fungal infection (Guzel et al., 2011).

\section{Candida albicans Rapid Test Device}

In our study the rapid test was more sensitive than wet mount $(87.9 \%$ versus $64.5 \%$ respectively ) and had the specificity of (98.4\% versus $96.9 \%$ for culture ). The negative predictive value was $96.9 \%$ and the positive predictive value of $93.1 \%$. This is in accordance with the study done by Marot-Leblond et al., (2009) in France who studied the efficient diagnosis of Vulvovaginal Candidiasis by using a New Rapid Immunochromatography Test (ICT). They found that the test had a significantly higher sensitivity (96.6\%) than microscopic examination $(61.6 \%)$ and a higher specificity $(98.6 \%)$ than fungal culture, they found that the sensitivities of microscopic examination, culture, and ICT for the diagnosis of VVC were $61 \%, 100 \%$ and $96.6 \%$, respectively, while the specificities of the three methods were $100 \%, 82 \%$, and $98.6 \%$, respectively and found that ICT had a negative predictive value of $98.6 \%$, a positive predictive value of $96.6 \%$. They found also that there is no cross-reactivity with human molecules or other microorganisms. But the limitation of the StrongStep ${ }^{\circledR}$ Candida albicans Rapid Test is that this test does not differentiate between viable and non-viable organisms and between individuals that are carriers and individuals that have an acute infection. A negative result may be obtained if the specimen collection is inadequate or if antigen concentration is below the sensitivity of the test. So the culture remain the gold standard but it needs 2-3 days to complete and get the diagnosis which delay the intiatation of the treatment.

\section{CONCLUSION}

The StrongStep Candida albicans Rapid Test is a point-of-care test for qualitative detection of Candida albicans in vaginal swabs within 10-20 minutes. It is an important advance in improving the diagnosis of women with $\mathrm{VVC}$, in addition this test is easy to perform, and the results are simple to interpret. The test is convenient for use by physicians during patient consultations. 


\section{REFERENCES}

Adib, S.M.; Bared, E.E.L.; Fanous, R.; Kyriacos, S. (2011). Practices of Lebanese gynecologists regarding treatment of recurrent vulvovaginal candidiasis. North Am. J. Med. Sci. 3, 406-410.

Al-Karim, M.; Maarouf, M.; Chahine, E. (2007). The role of personal and medical factors and general state in fungal vaginitis in Syrian women. J. Damascus Univ. Health Scien. 23(1), 239-249 .(In Arabic with English abstract).

Al-Karim, M.; Maarouf, M.; Chahine, E. (2005). Importance of the Culture in Identification of Fungal Vaginal Infections. SCLA, J. Lab. diagnosis, 3(7), (In Arabic with English abstract)

Al-Quaiz, J. M. (2000). Patients with vaginal discharge. A survey in university primary care clinic in Riyadh city. Ann. Saud. Med; 20(3-4), 302-306.

Begum, S.H. (2004). Study of vaginal discharge due to Trichomonas vaginalis and Candida albicans. Thesis for Degree of MD Obstetrics and Gynecology, Tribhuvan University, Kathmandu. Nepal.

Denfert, C.; Hube, B. (2007). "Candida: Comparative and Functional Genomics". Caister Academic Press. ISBN 9781904455134.

Evans, E. G., Lacey, C. J.; Carney, J. A. (1986). Criteria for the diagnosis of vaginal candidosis: evaluation of a new latex agglutination test. Eur. J. Obstet. Gynecol. Reprod. Biol. 22, (365-371). [PubMed]).

Gordis, L. (1996). "Medical Epidemiology". Sannders, Philadelphia, U.S.A. pp. 59-70.

Goswami, R.; Dadhwal, V.; Tejaswi, S.; Datta, K.; Paul, A.; Haricharan, R. N.; Banerjee, U.; Kochupillai, N.P. (2000). Species-specific prevalence of vaginal candidiasis among patients with diabetes mellitus and its relation to their glycaemic status. $J$. Infect. 41, 162-66.

Guzel, A.B.; Ilkit, M.; Akar, T.; Burgut, R.; Demir, S. C. (2011). Evaluation of risk factors in patients with vulvovaginal candidiasis and the value of chrom ID Candida agar versus CHRO Magar Candida for recovery and presumptive identification of vaginal yeast species. Med. Mycol. 49(1), 16-25.

Isibor, J. O.; Eghubare, A. E.; Omoregie, R. (2005). Germ tube formation in Candida albicans. Shiraze Med. J. 6 (1 and 2).

Linda, O.; Eckert, M. D. ( 2006). Acute Vulvovaginitis, N. Engl. J. Med . 355, 1244-1252.

Marot-Leblond, A.; Nail-Billaud, S.; Françoise Pilon; Beucher, B. ; Poulain, D.; Robert, R. (2009). Efficient Diagnosis of Vulvovaginal Candidiasis by Use of a New Rapid Immunochromatography Test. J. Clin. Microbiol. 47(12), 3821-3825.

Nester, E. W.; Denise, G.; Anderson, C. (2007). "Microbiology". 5th edn. chapter 26. pp. 657-675.

Nviriesy, P. (2008). Vulvovaginal candidiasis and bacterial vaginosis. Infect Dis. Clin. North Am. 22, 637-652.

Ozturk, C. E.; Ozdemir, I.; Yavus, T.; Kaya, T.; Behcet, M. (2006). Etiological agent of cervicovaginitis in Turkish women. Saudi Med. J., 27(10), 1503-1507.

Reed, B. D.; Pierson, C. L. (1992). Evaluation of a latex agglutination test for the identification of Candida species in vaginal discharge. J. Am. Board Fam. Pract. 5, 375-380. [PubMed]. 
Sobel, J. K.; Faro, S.; Force, R.W.; (1998). Volvovaginal candidiasis: Epidemiologic, diagnostic and therapeutic considerations. American J. Obstetrics and Gynecol. 178(2).

Thulkar, J. ; Kriplani, A.; Agarwal, N. (2010). Utility of pH test and Whiff test in syndromic approach of abnormal vaginal discharge. Indian J. Med. Res. 131, 445-448 .

Warren, T. (2010). "Is It a Yeast Infection?". http://women.webmd.com/features/is-it-yeastinfection. Retrieved

Yehia, M. M. (2009). Identification of fungi in lower respiratory tract infection among immunocompetent and immunocompromised patients. $\mathrm{Ph}$. D. Thesis. College of Medicine, University of Mosul, Iraq. 